\title{
MODEL PEMBELAJARAN KREATIF DAN PRODUKTIF \\ BERBASIS MASALAH KONTEKSTUAL MELALUI KEGIATAN \\ LESSON STUDY UNTUK MENINGKATAN \\ KREATIVITAS EKSPRESI TULIS PUISI
}

\author{
(IMPELENTATION OF CREATIVE AND PRODUCTIVE \\ STUDYING MODEL BASED ON CONTEXTUAL PROBLEM THROUGH LESSON \\ STUDY TO INCREASE THE EXPRESSIVE POETRY WRITING)
}

\author{
Lalu Fakihuddin \\ Universitas Hamzanwadi \\ Jalan TGKH Zainuddin Abdul Madjid No.132 Pancor 83612, Selong, NTB, Indonesia \\ Pos-el: fakihuddinlalu@yahoo.co.id
}

Diterima: 21 Agustus 2017; Direvisi: 7 November 2017; Disetujui: 27 November 2017

\begin{abstract}
The purposes of the research are (1) to increase the activity of student in writing poem by applying creative and productive studying model through Lesson Study activities; and (2) to increase the quality of expressive poetry writing process through Lesson Study activities. In order to achieve the goals, Lesson Study includes planning, executing, and observing. The all three stages have been done in four time/cycles in the Lesson Study lectures. Lectures and every cycle (1 to 4), had been focused on expressive modern poetry writing based on topic such as private name, disastrous event, beauty of nature, social events/problem, and political problem. Every part of study has been presented/done in creative and productive studying model which is based on fundamental principles of creative and productive learning such as orientation, exploration, interpretation, and re-creation. The result of this research are (1) implementation of creative and productive studying model based on contextual problem through Lesson Study activity in creative literature writing, especially modern poetry writing can increase the creativity of students, (2) creative and productive studying model through Lesson Study activity can increase quality of creative literature writing subject. It can be seen from the increasing in liveliness, self-service and cooperation and motivation of the student in solving tasks that had been assigned in the study. It is noteworthy that students also think that this method is interesting and enjoyable.
\end{abstract}

Keywords: creative and productive, contextual, lesson study, expressive poetry writing

\begin{abstract}
Abstrak
Tujuan penelitian ini, yaitu (1) untuk meningkatkan kreativitas menulis puisi mahasiswa dengan penerapan model pembelajaran kreatif dan produktif melalui kegiatan lesson study; dan (2) untuk meningkatkan kualitas proses pebelajaran ekspresi tulis puisi melalui kegiatan lesson study.Untuk mencapai tujuan tersebut, digunakan lesson study sebagai metode/kajian sederhana, melalui tahapan plan, do, dan see. Ketiga tahapan ini dilaksanakan dalam 4
\end{abstract}


kali/siklus perkuliahan LS. Pelaksanaan perkuliahan di setiap siklus (1 sampai dengan 4), difokuskan pada kegiatan ekspresi tulis puisi modern berbasis nama pribadi, peristiwa bencana alam, objek keindahan alam, dan peristiwa/masalah sosial dan masalah politik. Pembelajaran setiap siklus dikemas dalam model pembelaran kreatif dan produktif dengan berpegang pada hakikat setiap langkah pembelajaran kreatif dan produktif, yakni orientasi, eksplorasi, interpretasi, dan re-kreasi. Hasil yang diperoleh darii penelitian ini, yaitu: (1) Penerapan model pembelajaran kreatif dan produktif berbasis masalah-masalah kontektual melalui kegiatan lesson study di dalam pembelaran Penulisan Kreatif Sastra, khususnya pada masalah ekspresi tulis puisi modern dapat meningkatkan kreativitas mahasiswa. (2) Model pembelajaran kreatif dan produktif melalui kegiatan lesson study dapat meningkatkan kualitas pembelajaran Penulisan Kreatif Sastra. Hal ini tampak pada meningkatnya keaktifan, kemandirian, kerja sama, dan motivasi mahasiswa dalam menyelesaikan tugastugas dalam pembelajaran. Perlu juga digarisbawahi, mahasiswa menganggap pembelajaran ini menarik dan menyenangkan.

Kata kunci: kreatif dan produktif, kontekstual, lesson study, ekspresi tulis puisi

\section{Pendahuluan}

UU Guru dan Dosen, 2005, Pasal 1, ayat1 menjelaskan , "Guru/dosen adalah pendidik profesional dengan tugas utama mendidik, mengajar, membimbing, mengarahkan, melatih, menilai, dan mengevaluasi peserta didik... (UU Guru dan Dosen, 2005, pasal 1, ayat 1). Dalam UU Sisdiknas, 2003, pasal 1 ayat 1 juga dijelaskan, "Pendidikan adalah usaha sadar dan terencana untuk mewujudkan suasana belajar dan proses pembelajaran agar peserta didik secara aktif mengembangkan dirinya untuk memiliki kekuatan spiritual keagamaan, pengendalian diri, kepribadian, kecerdasan, akhlak mulia, serta keterampilan yang diperlukan dirinya, masyarakat, bangsa, dan negara."

Berdasarkan amanat UU Sisdiknas tersebut, seorang dosen/guru hendaknya menjadi pendidik profesional yang tugasnya bukan saja mengajar tetapi juga mendidik, mengajar, membimbing, mengarahkan, melatih, menilai, dan mengevaluasi peserta didik. Salah satu upaya untuk menjadikan guru/dosen profesional adalah pembaharuan/perbaikan terkait dengan mindset para dosen/guru supaya dalam melaksanakan perkuliahan/pembelajaran dapat berkolaborasi dan berbagi pengalaman dengan dosen/guru lain dan lebih terbuka demi perbaikan perkuliahan. Untuk menuju kondisi tersebut, Pendekatan Lesson Study dipandang tepat sebagai alternatif untuk memperbaiki mindset dosen program studi Pendidikan Bahasa dan Sastra Indonesia (PBSI) dan meningkatkan kualitas perkuliahan. Lesson study diperlukan, khususnya bagi dosen PBSI, antara lain berangkat dari salah satu permasalahan pendidikan di Indonesia, tidak terkecuali di Prodi PBSI Universitas Hamzanwadi, yakni pembelajaran lebih menekankan pada ranah kogniif tingkat rendah (mengingat, memahami, 
dan menerapkan), sedangkan ranah kognitif tingkat yang lebih tinggi seperti menganalisis, menilai/mengevaluasi masih "kurang tersentuh".

Salah satu mata kuliah yang dipilih oleh Prodi PBSI untuk di-lesson study-kan adalah Penulisan Kreatif Sastra. Alasan utama pemilihan mata kuliah ini adalah karena salah satu kelemahan sebagian besar mahasiswa adalah menuangkan gagasannya ke dalam bahasa tulis, tidak terkecuali Menulis Kreatif Sastra. Mata kuliah ini termasuk mata kuliah wajib bagi mahasiswa Program Studi Pendidikan Bahasa dan Sastra Indonesia di Universitas Hamzanwadi. Mata kuliah ini bertujuan: (1) menampung dan menumbuhkan minat mahasiswa dalam bidang penulisan kreatif sastra dan (2) mengasah kemampuan mahasiswa dalam bidang menulis sehingga mampu menulis berbagai jenis karya kreatif sastra. Kemampuan tersebut selanjutnya diharapkan dapat menjadi salah satu kecakapan hidup (life skill) yang dimiliki mahasiswa, antara lain kecakapan sebagai penulis/pengajar sastra di sekolah. Bidang penulisan kreatif sastra meliputi berbagai kegiatan ekspresi tulis karya sastra, yakni ekspresi tulis puisi (modrn), ekspresi tulis karya sastra prosa (cerpen, novel), dan ekspresi tulis naskah drama.

Garis besar isi mata kuliah Menulis Kreatif Sastra adalah hakikat menulis kreatif dan manfaat menulis kreatif, modal dasar penulis karya kreatif/sastra, meningkatkan kekayaan bahasa, imajinasi, melakukan ekspresi tulis puisi modern berbasis nama pribadi, keindahan/objek alam, dan peristiwa dalam kehidupan, ekspresi tulis prosa (cerpen) berbasis pengalaman pribadi, dan ekspresi tulis prosa (naskah drama) berbasis cerpen/cerita rakyat. Dari beberapa materi/topik yang diajarkan dalam mata kuliah ini, salah satu di antaranya yang dipilih untuk di-lesson study-kan ialah Ekspresi Tulis Puisi Modern.

Ekspresi tulis puisi adalah kegiatan yang memungkinkan kita mendapatkan pengalaman artistik dalam menulis puisi. Pada saat kita menemukan peristiwa yang luar biasa, misalnya melihat jatuhnya pesawat, tenggelamnya kapal, gelapnya siang hari akibat letusan gunung berapi, melihat porak-porandanya suatu daerah akibat bencana alam (gempa bumi, tsunami, angin topan, dll.). Semua ini adalah bahan-bahan yang tersaji yang dapat diolah menjadi sebuah karya kreatif yang disebut puisi. Lewat ekspresi tulis puisi, mahasiswa dapat mengekspresikan dirinya karena pada hakikatnya manusia sebagai homo ludns (makhluk bermain) dan homo fabulans (makhluk bersastra).

Mengapa fokus/masalah yang dipilih untuk di-lesson study-kan itu menulis puisi? Berdasarkan hasil pengamatan terhadap hasil latihan menulis puisi yang dilakukan di awal perkuliahan, ditemukan bahwa mahasiswa Program Studi Pendidikan Bahasa dan Sastra Indonesia (peserta lesson study) memiliki tingkat kreativitas yang tergolong masih rendah. 
Hal ini tampak pada kretivitas mereka menuangkan gagasan, pengalaman, penghayatan dalam ekspresi tulis puisi masih sebatas merangkai keindahan kata. Masih sebagian besar mahasiswa kurang memanfaatkan berbagai unsur estetika dalam puisi, seperti minimnya penggunaan rima, kata-kata simbolik, penggunaan image, dan pemanfaatan majas dalam merangkai larik-larik puisi. Padahal unsur-unsur tersebut merupakan syarat dalam menciptakan kreativitas menulis puisi yan tidak saja untuk mencapai efek estetik, tetapi juga untuk mencapai efektivitas penyampaian pesan penyair/penulis.

Peningkatan kreativitas mahasiswa dalam kegiatan ekspresi tulis puisi bisa terwujud melalui penerapan lesson study dalam perkuliahan yang terkait dengan sastra, khususnya Penulisan Kreatif Sastra dengan menerapkan model pembelajaran kreatif dan produktif. Model pembelajaran kreatif dan produktif pada awal mulanya dirancang untuk pembelajaran apresiasi sastra (Depdiknas, 2005). Namun, dalam perkembangannya kemudian, dengan beberapa modifikasi), model ini dapat digunakan untuk berbagai bidang studi. Model ini pada awalnya disebut strategi strata (Wardani, via Depdiknas, 2005). Setelah mendapatkan berbagai modifikasi, model ini diberi label Pembelajaran Kreatif dan Produktif.

\section{Kerangka Teori}

Untuk menghindari kesimpangsiuran terhadap beberapa istilah yang dilakukan dalam kajian ini, perlu disajikan secara ringkas beberapa hal terkait dengan varibel kajian, yakni kreaivitas, ekspresi tulis puisi, model pembelajaran kreatif dan produktif, lesson study.

\subsection{Kreativitas}

Kreativitas berasal dari bahasa Inggris "create" (v) dan "creation" (n). Create atau berkreasi dalam bahasa Indonesia berarti 'menciptakan', 'menjadikan', 'menghasilkan', 'membuat', 'melahirkan', dan 'mengadakan' (Herpinus Simanjuntak, 1986:63). Sedangkan dalam bentuk kata benda (n), terdapat kata creation atau kreasi (dalam bahasa Indonesia) berarti: ciptaan, hasil. Berdasarkan makna kata tersubut, kata kreatif/kreativitas yang dimaksud dalam kajian ini, yaitu mempunyai kemampuan untuk mencipta atau memiliki daya cipta, suatu pekerjaan yang memiliki daya cipta (Poerwadarminta, 1986:526).

\subsection{Ekspresi Tulis Puisi}

Yang dimaksud ekspresi tulis puisi dalam kajian ini adalah kegiatan yang memungkinkan seseorang mendapatkan pengalaman artistik dalam menulis puisi. Dengan kata lain, mengungkapkan ide, perasaan, imajinasi, pengalaman, dan lain-lain ke dalam kegiatan menulis puisi. 


\subsection{Model Pembelajaran Kreatif dan Produktif}

Model pembelajaran kreatif dan produktif pada awal mulanya dirancang untuk pembelajaran apresiasi sastra (Depdiknas, 2005). Namun dalam perkembangannya kemudian, dengan beberapa modifikasi), model ini dapat digunakan untuk berbagai bidang studi. Model ini pada awalnya disebut strategi strata (Wardani, via Depdiknas, 2005). Setelah mendapatkan berbagai modifikasi, model ini diberi label Pembelajaran Kreatif dan Produktif.

Jadi, model pembelajaran kratif dan produktif yang dimaksud di sini, yaitu pembelajaran yang dikemas ke dalam 5 langkah/struktur pembelajaran Kreatif dan Produktif, yakni (1) orientasi, yakni dosen model dan mahasiswa sebelumnya menyepakati tugas yang akan ditempuh. Di luar tatap muka, dosen model sudah terlebih dahulu bertemu dengan mahasiswa mengomunikasikan tujuan, materi, waktu, langnkah, dan hasil akhir yang diharapkan dari mahasiswa, serta hal-hal yang dijadikan unsur-unsur penilaian. Langkah selanjutnya, (2) eksplorasi, yaitu mahasiswa melakukan kegiatan membaca contoh-contoh puisi yang terkait dengan materi/topik perkuliahan, mengamati contoh yang diberikan, mencari di internet, dll. Eksplorasi singkat dilakukan pada saat jam perkuliahan, yakni dengan mengamati tayangan-tangan lewat power point/film you tube, dsb. Langkah berikutnya, (3) interpretasi yaitu dengan mengidentifikasi/memilih salah satu karya puisi terbaik dari masing-masing kelompok, mempresentasikan puisi yan dipilih, masing-masing kelompok mempresentasikan hasil kerjanya, kelompok lain memberikan tanggapan presetasi kelompok, dan responsi/klarifikasi dari dosen. Langkah terakhir dari struktur pembelajaran kreatif dan produktif, yaitu re-kreasi. Dalam langkah ini mahasiswa ditugaskan untuk menghasilkan sesuatu yang mencerminkan pemahamannya terhadap konsep/topik/masalah yang dikaji/dipelajari. Dalam pelaksanaan kuliah ini, mahasiswa diminta mengedit kembali puisi hasil karyanya sehingga lebih memenuhi unsur karya puisi sebagai hasil karya kreatif.

\subsection{Lesson Study}

Konsep lesson study yang dipakai dalam kajian ini, yaitu suatu cara efektif untuk meningkatkan kualitas pembelajaran melalui pengembangan keprofesionalan yang dilaksanakan secara kolaboratif berdasarkan pembelajaran melalui lesson study (Stigler dan Hiebert melalui Eti Setiawati, dkk. 2009:15-16). Lesson study mencakup tiga tahap pembelajaran, yaitu (1) tahap perencanaan (plan), tahap implementasi dan observasi (do), dan (3) tahap kegiatan refleksi (see). 


\section{Metode Penelitian}

Untuk mencapai tujuan yang diharapkan, yaitu meningkatkan kreativitas mahasiswa dalam menulis puisi melalui penerapan model pembelajaran kreatif dan produktif dan meningkatkan kualitas proses pembelajaran ekspresi tulis puisi, digunakan lesson study sebagai metode/kajian sederhana, melalui tahapan plan, do, dan see. Ketiga tahapan ini dilaksanakan dalam 4 kali/siklus perkuliahan. Pelaksanaan perkuliahan di setiap siklus (1 sampai dengan 4), difokuskan pada kegiatan ekspresi tulis puisi modern berbasis nama pribadi, peristiwa bencana alam, objek keindahan alam, dan peristiwa/masalah sosial dan masalah politik. Pembelajaran setiap siklus dikemas dalam model pembelaran kreatif dan produktif dengan berpegang pada hakikat setiap langkah pembelajaran kreatif dan produktif, yakni orientasi, eksplorasi, interpretasi, dan re-kreasi. Untuk tahapan rekreasi terkadang tidak dilakukan dalam pembelajaran tatap muka karena waktu yang tersedia tidak mencukupi. Untuk mengatasinya, tahap re-kreasi ini diganti dengan penugasan mahasiswa menulis sebuah puisi yang mencerminkan pemahamannya terhadap konsep/topik/masalah yang dikajinya misalnya dengan menulis kembali/mengedit kembali karya puisi yang telah dihasilkannya agar lebih sesuai dengan indikator yan telah ditentukan.

Untuk mendapatkan data empirik yang benar-benar sahih terkait dengan fokus kajian, sumber data diambil dari dosen dan mahasiswa yang terkait dengan kegiatan Lasson Study pada mata kuliah Penulisan Kreatif Sastra. Adapun nama-nama dosen yang terlibat langsung dengan kegiatan ini: Drs. Lalu Mas ud, M.Pd., Mudjito, Ph.D., Muhammad Irfan, M.Pd., Dra. Hj. Fitriyah, M.Pd., Drs. Lalu Muh. Hidlir, M.Pd., Muhammad Jaelani Alfansori, M. Pd., Syahrial Akbar, M.Pd., Hari Nur Cahyanto, M.Hum., dan Yudi W. Himawan, M.A.

Lesson studi dalam mata kuliah Penulisan Kreatif Sastra ini dirancang dalam 4 putaran/siklus dilaksanakan dalam 3 tahapan, yakni: (1) perencanaan/plan, melaksanakan perkuliahan berdasarkan RPP yang telah disiapkan/do disertai dengan kait kegiatan obervasi oleh tim observer tim LS, juga didokumentasikan oleh anggota tim yang telah ditentukan, dan (3) melakukan diskusi refleksi berdasarkan hasil observasi yang dilakukan observer.

Pada tahapan perencanaan (plan), tim Lasson Study melakukan pengkajian bersama terkait dengan perangkat perkuliahan, meliputi silabus mata kuliah Penulisan Kreatif Sastra, rencana pelaksanaan perkuliahan (RPP), materi perkuliahan (teaching material), LKM, instrumen evaluasi, dan media serta alat yang akan digunakan. Hasil pengkajian tim selanjutnya dijadikan bahan perbaikan/penyempurnaan perangkat yang telah disusun.

Pada tahapan pelaksanaan $(d o)$, dosen model melaksanakan perkuliahan sesuai dengan perangkat yang sudah mendapatkan pengkajian oleh tim Lasson Study dan telah 
direvisi sesuai dengan masukan tim. Ketika dosen model melakukan proses perkuliahan, tim yang bertindak sebagai observer melakukan kegiatan observasi pelaksanaan pembelajaran. Fokus observasi adalah aktivitas belajar mahasiswa. Observasi dilkukan secara terstandar, berpedoman pada lembar observasi yang telah disiapkan. Kegiatan ini juga dilengkapi dengan pendokumentasian aktivitas dosen model dan mahasiswa yang belajar. Hal ini dimaksudkan untuk memperkuat hasil observasi.

Tahap tahapan refleksi (see), dilakukan segera setelah tahapan pelaksanaan perkuliahan selesai dilaksanakan, kecuali pada OC 1 tidak segera dilakukan karena ada kendala waktu dan teknis. Kegiatan ini diikuti oleh semua tim LS yang hadir pada waktu Open Class, yakni Ketua Program Studi PBSI, dosen model, desen bserver, dan seorang monevin. Pada kegiatan ini moderator mengantar dan membuka diskusi refleksi, selanjutnya menyilakan dosen model terlebih dahulu menyampaikan refleksi terkait dengan pembelajaran yang baru saja dilakukan. Selanjutnya, masukan dari tim observer dan monevin. Setelah semua observer dan tim monevin memberi masukan, moderator memperlikan kembali dosen model memberikan tanggapan balik. Selanjutnya tim berdiskusi terkait dengan kelemahankelemahan pembelajaran yang muncul dan sakaligus mendiskusikan pemecahannya agar tidak terulang pada pelaksanaan pembelajara OC selanjutnya.

Data yang dikumpulkan adalah yang terkait langsung dengan ekspresi tulis puisi, meliputi: (1) keharmonisan ide dengan masalah yang menjadi fokus pembelajaran, (2) unsur fungsionalisasi yang mendukung, seperti penggunaan rima (persajakan), dan (3) unsur kreativitas, seperti pemanfaatan bahasa simbolik, imaji, dan majas. Teknik pengumpulan data terkit dengan unsur-unsur tersebut dilakukan dengan menugaskan mahasiswa menulis puisi. Instrumen pengumpulan data yang digunakan, yaitu rubrik penilaian dan penskoran, hasil observasi yang dilakukan oleh tim observer selama pelaksanaan $(\mathrm{do})$, dan lembar angket yang dibagikan dan telah diisi mahasiswa.

Pada kegiatan analisis data, untuk mendeskripsikan peningkatan kreativitas mahasiswa dalam menulis puisi, dilakukan penskoran setiap unsur di setiap kegiatan OC, selanjutnya diklasifikasikan, serta data dianalisis secara deskriptif. Untuk data yang terkait dengan proses perkuliahan, dilakukan analisis isi hasil observasi dan angket yang dibagikan kepada observer dan mahasiswa. 


\section{Pembahasan}

\subsection{Hasil Perencanaan Pembelajaran}

Sebelum kegiatan plan dilakukan bersama tim LS, dosen model (Drs. Lalu Fakihuddin, M.Pd.), selanjutnya disebut LF terlebih dahulu menyusun perangkat pembelajaran yang terdiri atas silabus mata kuliah Penulisan Kreatif Sastra (RPS) dan rencana pelaksanaan perkuliahan (RPP). RPS yang disusun meliputi: identitas mata kuliah, deskripsi singkat, standar kompetensi, kompetensi dasar, indikator, pelaksanaan proses perkuliahan, buku sumber, dan rencana kegiatan perkuliahan. RPP kegiatan OC1 dan OC2 disampaikan/diplankan bersama-sama. Untuk kegiatan OC1 mengambil topik/materi "Ekspresi Tulis Puisi Berbasis Nama Diri” (mengurai nama diri). Sedangan untuk kegiatan OC2 mengambil topik “Ekspresi Tulis Puisi Berbasis Peritiwa Alam” (Bencana Alam). Dua RPP ini dismpaikan secara terbuka kepada tim LS Program Studi Pendidikan Bahasa dan Sastra Indonesia, tepatnya empat hari sebelum pelaksanaan/do OC1 tanggal 08 November 2013. Beberapa masukan dan saran diberikan oleh tim LS Prodi PBSI, diantaranya masalah indikator, media dan alat, pendekatan dan metode, langkah-lankah pembelajaran, dan lembar kerja mahasiswa. Langkah-lankah yang hampir sama dilakukan terkait pembelajaran siklus III dan IV (OC3 dan OC4). Pada plan untuk OC3 dan OC4 ini dipimpin langsung oleh Prodi PBSI dan penyajian perangkat diperankan langsung oleh Drs. Lalu Fakihuddin, M.Pd. selaku dosen model. RPP OC3 mengambil materi "Ekspresi Tulis Puisi Berbasis keindahan alam". Adapun materi untuk OC4 mengambil materi "Ekspresi Tulis Puisi Berbasis masalah sosial dan politik, khususnya yang terjadi di Indonesia. Pada Plan ini beberapa masukan penting disampaikan oleh tim, di antaranya bagaimana merancang kegiatan pembelajaran supaya waktu bisa lebih efektif dan efisien. Juga pemanfaatan media seperti IPAD untuk menayangkan hasil karya mahasiswa dan strategi dalam diskusi kelompok.

\subsection{Hasil Pelaksanaan Pembelajaran}

Pada siklus I, dosen model (LF) melaksanakan pembelajaran dengan standar kompetensi "mengungkapkan pikiran, perasaan, pengalaman, dan imajinasi ke dalam kegiatan ekspresi tulis puisi (modern) berbasis nama pribadi, keindahan alam, peristiwa alam, dan masalah sosial dan politik". Langkah pembelaran yang ditempuh mengikuti struktur pembelajaran Kreatif dan Produktif. Namun, struktur pembelajaran ini tidak ditampakkan secara eksplisit dalam RPP. Pembelajaran dimulai dengan orientasi, yakni dosen model dan mahasiswa sebelumnya menyepakati tugas yang akan ditempuh. Di luar tatap muka, dosen model sudah terlebih dahulu bertemu dengan mahasiswa mengomunikasikan tujuan, materi, waktu, langkah, dan hasil akhir yang diharapkan dari 
mahasiswa, serta hal-hal yang dijadikan unsur-unsur penilaian. Langkah selanjutnya, eksplorasi, yaitu mahasiswa melakukan kegiatan membaca contoh-contoh puisi yang terkait dengan materi/topik perkuliahan, mengamati contoh yang diberikan, mencari di internet, dll. Eksplorasi singkat dilakukan pada saat jam perkuliahan, yakni dengan mengamati tayangantangan lewat power point/film you tube, dsb. Langkah berikutnya, interpretasi yaitu dengan mengidentifikasi/memilih salah satu karya puisi terbaik dari masing-masing kelompok, mempresentasikan puisi yan dipilih, masing-masing kelompok mempresentasikan hasil kerjanya, kelompok lain memberikan tanggapan presentasi kelompok, dan responsi/klarifikasi dari dosen. Langkah terakhir dari struktur pembelajaran kreatif dan produktif, yaitu re-kreasi. Dalam langkah ini, mahasiswa ditugaskan untuk menghasilkan sesuatu yang mencerminkan pemahamannya terhadap konsep/topik/masalah yang dikaji/dipelajari. Dalam Pelaksanaan kuliah ini mahasiswa diminta mengedit kembali puisi hasil karyanya sehingga lebih memenuhi unsur karya puisi sebagai hasil karya kreatif. Pengalaman beharga yang diperoleh dalam pembelajaran siklus I adalah sebagian terbesar mahasiswa belum menunjukkan kreativitasnya dalam menulis puisi. Hal ini tampak pada hasil karya mereka masih bersifat prosais, belum hemat kata, belum memperhatikan persajakan, ritme, dan metrum. Mereka lebih banyak memaknai karya puisi dengan bermain dengan keindahan kata-kata. Sebagai contoh dapat dilihat pada lampiran).

Pada siklus II, dosen model kembali melaksanakan pembelajaran dengan menerapkan model pembelajaran kreatif dan produktif dengan mengikuti langkah pembelajaran seperti yang telah diterapkan pada siklus pertama. Yang berbeda dari siklus ini, yaitu topik/masalah yang menjadi sumber inspirasi mahasiswa, ekspresi tulis puisi modern bebasis peristiwa alam/bencana alam dengan kompetensi dasar "melakukan kegiatan ekspresi tulis puisi berbasis peristiwa alam". Pada siklus kedua ini dosen model memancing ide mahasiswa dengan memutarkan film you tube tentang Tsunami Jepang dan Aceh.Yang berbeda juga dalam pelaksanaan do ini, mahasiswa bertukar karya puisi dengan anggota kelompok lain, dan memilih salah satu karya puisi unuk dikomentari sesuai dengn petunjuk LKS, selanjutnya melakukan re-kreasi dengan mengedit kembali puisi karya mereka. Pada siklus II ini mahasiswa menunjukkan perubahan dibandingkan dengan siklus I. Sebagaan besar puisi hasil karya mereka mulai hemat kata, mulai memerhatikan persajakan, dan dalam sebagian puisi muncul telah muncul pemakaian bahasa simbolik, kata konkret, dan penggunaan majas yang cukup efektif mengejar estetika puisi. Kemajuan ini dapat dilihat pada perubahan persentase kreativitas (bisa dicermati pada tabel kreativitas setiap OC). Pengalaman berharga dosen model di siklus ini, pemberian feed back dengan menunjukkan berbagai kelemahan dan 
menghadirkan puisi lain sebagai model ternyata dapat meningkatkan kualitas hasil karya mahasiswa.

Pada siklus III, dosen model melaksanakan pembelajaran dengan model yang sama, yaitu pembelajaran kreatif dan produktif. Kompetensi yan dikembangkan dalam siklus III ini adalah "melakukan kegiatan ekspressi tulis puisi berbasis objek keindahan alam". Proses perkuliahan sejak awal hingga akhir mengikuti langkah pembelajaran kreatif dan produktif, yakni orientasi, eksplorasi, interpretasi, dan re-kreasi. Perbedaan pada siklus III ini terletak pada tayangan media yang disesuaikan dengan KD, yakni gambar keindahan pantai, air terjun, lautan, dan hutan. Mahasiswa diminta mengamati tayangan, mencatat ide-ide penting dari tayangan, selanjutnya berkreasi menulis karya puisi dengan memanfaatkan ide dalam tayangan, dipadu dengan imajinsi, serta kreasi mereka. Yang juga berbeda dengan pembelajaran sebelumnya, yaitu unsur yang harus diperhatikan lebih bersifat spesifik, yakni harmonisasi ide, penggunaan rima/persajakan, dan penggunaan image dan bahasa figuratif/majas. Hasil pembelajaran pada siklus ini menunjukkan peningkatan yang signifikan. Persentase peningkatan terutama dalam pemanfaatan rima semakin naik, kreativitas dalam memanfaatkan bahasa figuratif semakin baik, begitu juga dengan pengimajian. Hal ini tidak lepas dari diskusi dosen dan mahasiswa pada waktu pembahasan kembali hasil karya siswa pada OCII. Pengalaman berharga dosen model dalam siklus ini yaitu jika media dan objek yang menjadi sumber ide dalam penulisan puisi menarik dan disukai mahasiswa, hasil karyanya pun lebih baik. Untuk membuktikan hal ini bisa dicermati pada lampiran puisi mahasiswa.

Pada siklus IV, dosen model (Lalu Fakihudddin) melaksanakan pembelajaran dengan model yang sama, yaitu pembelajaran kreatif dan produktif. Pelaksanaan siklus ini pada tanggal 29 November 2013. Kompetensi yang dikembangkan dalam siklus IV ini adalah "melakukan kegiatan ekspressi tulis puisi berbasis masalah sosial dan masalah politik". Proses perkuliahan sejak awal hingga akhir mengikuti langkah pembelajaran kreatif dan produktif, yakni orientasi, eksplorasi, interpretasi, dan re-kreasi. Perbedaan pada siklus IV ini terletak pada tayangan media yang disesuaikan dengan KD, yakni video you tube tentang masalah politik, seperti demonstrasi di Mahkamah Konstitusi, demonstrasi di Seragen, video pembantu rumah tangga menyiksa bayi yang tak berdosa, dan tewasnya perampok toko emas. Mahasiswa diminta mengamati tayangan dan mencatat ide-ide penting yang dilihat terkait masalah sosial politik. Selanjutnya mereka berkreasi menulis karya puisi dengan memanfaatkan ide dalam tayangan, dipadu dengan imajinsi, serta kreasi mereka. Unsur yang harus diperhatikan lebih bersifat spesifik, yakni harmonisasi ide, penggunaan 
rima/persajakan, dan penggunaan image dan bahasa figuratif/majas. Yang berbeda dengan siklus sebelumnya adalah pemanfaatan media IPAD untuk presentasi hasil karya mahasiswa. Dari segi proses pembelajaran, siklus ini lebih efektif dibandingkan dengan sebelumnya karena dengan bantuan media IPAD yang ditayangkan oleh salah seorang tim LS, pembelajaran lebih efektif, karena karya siswa tidak hanya dinikmati oleh yang mempresentasikan, tetapi juga oleh seluruh mahasiswa. Pengalaman ini sangat berharga bagi kami. Penguasaan media dan pemanfaatan media secara tepat dapat mengefektifkan pembelajaran. Hasil karya mahasiswa belum diketahui karena belum semua diperiksa.

\subsection{Hasil Refleksi Pembelajaran}

Refleksi pada putaran/siklus I, II, III, dan IV dilaksanakan segera setelah pelaksanaan pembelajaran setiap Open Class dilaksanakan. Refleksi setiap OC dilaksanakan untuk mendapatkan masukan terkait dengan kekurangan-kekurangan yang masih tampak dalam proses perkuliahan, khususnya dilihat dari aktivitas para mahasiswa. Hal ini dimaksudkan sebagai upaya peningkatan kualitas pembelajaran pada OC selanjutnya sesuai dengan fokus masalah ekspresi tulis puisi, khususnya dan Penulisan Kreatif Sastra Umumnya.

\subsection{Kreativitas Mahasiswa}

Tabel 1: Frekuensi skor dan persentase (kegiatan OC1)

\begin{tabular}{|l|c|c|c|c|}
\hline \multicolumn{1}{|c|}{ Unsur penilaian } & \multicolumn{4}{c|}{ Frekuensi skor dan persentase } \\
\hline & 1 & 2 & 3 & 4 \\
\hline Keharmonisan ide & - & 10 & 13 & 5 \\
& & $(35,71)$ & $(46,42)$ & $(17,85)$ \\
\hline Pemanfaatan rima,irama & 1 & 14 & 13 & - \\
$(3,57)$ & $(50)$ & $(46,42)$ & \\
\hline Penggunaan imaji, bahasa figuratif & - & 15 & 11 & 2 \\
$(53,57)$ & $(39,28)$ & $(7,14)$ \\
\hline Jumlah Karya/puisi & \multicolumn{4}{|c|}{28} \\
\hline
\end{tabular}

Tabel 2: Frekuensi skor dan persentase (kegiatan OC2)

\begin{tabular}{|l|c|c|c|c|}
\hline \multicolumn{1}{|c|}{ Unsur penilaian } & \multicolumn{4}{|c|}{ Frekuensi skor dan persentase } \\
\hline & 1 & 2 & 3 & 4 \\
\hline Keharmonisan ide & - & - & 17 & 11 \\
$(60,71)$ & $(39,28)$ \\
\hline Pemanfaatan rima, irama & - & 7 & 19 & 2 \\
$(25)$ & $(67,8)$ & $(7,14)$ \\
\hline Penggunaan imaji, bahasa figuratif & - & 9 & 15 & 4 \\
$(32,14)$ & $(53,57)$ & $(14,28)$ \\
\hline Jumlah Karya/puisi & \multicolumn{4}{|c|}{28} \\
\hline
\end{tabular}

Tabel 3: Frekuensi skor dan persentase (kegiatan OC3) 


\begin{tabular}{|l|c|c|c|c|}
\hline \multirow{2}{*}{ Unsur penilaian } & \multicolumn{4}{|c|}{ Frekuensi skor dan persentase } \\
\cline { 2 - 5 } & 1 & 2 & 3 & 4 \\
\hline Keharmonisan ide & & $\begin{array}{c}2 \\
(6,66)\end{array}$ & $\begin{array}{c}17 \\
(56,66)\end{array}$ & $\begin{array}{c}11 \\
(36,66)\end{array}$ \\
\hline Pemanfaatan rima, irama & & $\begin{array}{c}3 \\
(10)\end{array}$ & $\begin{array}{c}27 \\
(90)\end{array}$ & - \\
\hline Penggunaan imaji, bahasa figuratif & - & $\begin{array}{c}8 \\
(26,66)\end{array}$ & $\begin{array}{c}20 \\
(66,66)\end{array}$ & $\begin{array}{c}2 \\
(6,66)\end{array}$ \\
\hline Jumlah Karya/puisi & & \multicolumn{3}{|c|}{30} \\
\hline
\end{tabular}

Tabel 4: Frekuensi skor dan persentase (kegiatan OC4)

\begin{tabular}{|l|c|c|c|c|}
\hline \multicolumn{1}{|c|}{ Unsur Penilaian } & \multicolumn{4}{c|}{ Frekuensi skor dan persentase } \\
\hline & 1 & 2 & 3 & 4 \\
\hline Keharmonisan ide & & - & 15 & 15 \\
& & & $(50)$ & $(50)$ \\
\hline Pemanfaatan rima, irama & & 5 & 24 & 1 \\
& & $(16,66)$ & $(72)$ & $(3,33)$ \\
\hline Penggunaan imaji, bahasa figuratif & & $\begin{array}{c}11 \\
(36,66)\end{array}$ & $\begin{array}{c}17 \\
(56,66)\end{array}$ & $\begin{array}{c}\mid c \\
(6,66)\end{array}$ \\
\hline Jumlah Karya/puisi & & \multicolumn{4}{|c|}{30} \\
\hline
\end{tabular}

Data pada tabel (OC1-OC4) menunjukkan bahwa penerapan model Pembelajaran Kreatif dan Produktif melalui kegiatan lesson study dapat meningkatkan kreativitas mahasiswa dalam kegiatan ekspresi tulis puisi modern (Penulisan Kreatif sastra). Pembahasan berikut ini terkait dengan unsur yang menjadi fokus penilaian/peningkatan dalam kegiatan pembelajaran, sebagai berikut.

\section{a. Unsur Harmonisasi}

Unsur harmonisasi dalam penulisan puisi sangat penting untuk diperhatikan. Menurut Waluyo (1997/1998:62) harmonisasi dapat dikaitkan dengan efek yang dimunculkan. Mungkin unsur itu sengaja dibuat menjadi tidak selaras (disharmoni). Akan tetapi, hal itu difungsikan agar sesuai dengan tema, majas, irama, dan tifografi. Dalam kaitannya dengan pembelajaran dalam konteks lesson study ini, harmonisasi agak disederhanakan, yaitu terbatas pada keselarasan tema dengan ide yang membangun puisi secara keseluruhan, keselarasan ide antarlarik, dan antar bait. Setelah dicermati (berdasarkan data di atas), pada OC1 (Puisi Berbasis Nama Diri) diperoleh gambaran bahwa yang tergolong sangat harmonis (skor 4) sebanyak 5 orang (17,85\%), yang tergolong harmonis (skor 3) 13 orang (46,42\%), dan termasuk kurang harmonis (skor 2) 10 orang (35, 71\%). Pada OC 2 (Puisi Berbasis 
encana Alam), keharmonisan terjadi peningkatan, yakni 11 karya $(39,28)$ tergolong sangat harmonis dan 17 karya (60,71) tegolong harmonis. Pada Oc3 (Puisi berbasis keindahan alam), persentase yang tergolong sangat harmonis meningkat, yakni $11(36,66)$, kategori harmonis menurun dari OC2, yakni 17 orang $(56,66)$, dan 2 orang $(6,66)$ tergolong kurang harmonis. Pada OC 4 (puisi berbasis masalah sosial dan politik), untuk kategori sangat harmonis (skor 4) terdapat peningkatan, yakni 15 karya (50), untuk kategori harmonis 15 karya $(50 \%)$.

\section{b. Unsur Rima dan Irama (Ritme)}

Rima dalam puisi adalah pengulangan bunyi dalam puisi atau dalam istilah lain persajakan. Pengulangan bunyi ini tidak hanya terjadi pada akhir larik, tetapi juga pada keseluruhan bait atau puisi. Sedangkan irama atau ritme adalah pemotongan-pemotongan baris menjadi fase berulan-ulang sehingga dapat memperindah sebuah puisi. (Waluyo, 1987). Terkait dengan pemanfaatan rima dan ritma kaitannya dengan keidahan puisi jika dibacakan, mahasiswa PBSI STKIP Hamanwadi Selong/V, menunjukkan hasil sebagi berikut: Pada OC1 kreativitas dalam penggunaan rima dan irama masih kurang, yakni belum ada yang masuk kategori sangat fungsional, $11(46,42)$ tergolong fungsional, 14 (50) kurang fungsional, dan 1 $(3,57)$ dlam kategori sangat tidak fungsional. Pada Oc 2 (puisi berbasis bencana alam), terjadi peningkatan signifikan, yakni sangat fungsional 7 karya $(14,28)$, fungsional 19 karya $(67,8)$, kurang fungsional 7 karya (25\%). Pada OC3 (puisi berbasis keindahan alam), yang tergolong kategori sangat fungsional Ttidak ada), fungsional meningkat sangat signifikan, yakni 27 karya (90), dan 3 karya (10\%) kurang fungsional. Sedangkan pada siklus 4 (puisi berbasis masalah sosial-politik), untuk kategori sangat fungsional ada peningkatan, yakni 2 karya $(6,66)$, kategori fungsional $(56,66)$, dan kategori kurang fungsional 5 karya $(36,66)$.

\section{c. Unsur Pengimajian dan Bahasa Figuratif}

Pengimajian terkait erat dengan pengonkretan kata. Pengongkretan kata sangat penting dalam menlis puisi supaya pembaca dapat seolah-olah melihat, atau mendengar, atau merasakan apa yang dinyatakan penyair (Waluyo, dalam Sabarti Akhadiah, dkk. 1996/1997). Sedangkan bahasa figuratif atau sering disebut majas digunakan penyair untuk menyatakan sesuatu dengan cara tidak langsung mengungkapkan makna kata yang digunakan atau bermakna kias/lambang. Terkait dengan kreativitas mahasiswa dalam memanfaatkan kata konkret dan majas dalam karyanya, diperoleh hal berikut. Pada OC1 yang tergolong sangat kreatif sebanyak 2 karya (7,14\%), tergolong kreatif sebanyak 11 orang (39,8\%), dan yang kurang kreatif memanfaatkan sebanyak 15 karya (53,57\%). Pada OC 2, terjadi peningkatan, yaitu 4 karya $(14,28 \%)$ tergolong sangat kreatif, $15(53,57 \%)$ kreatif, dan 9 karya $(32,14 \%)$ 
masih kurang kreatif. Pada OC 3, terjadi peningkatan, yaitu 2 (6,66\%) masuk dalam kategori sangat kreatif, 20 karya $(66,66 \%)$ tergolong kreatif, dan 8 (26,66\%) kurang kreatif. Pada OC 4, pada kategori sangat kreatif tidak terjadi peningkatan, yakni 2 (6,66\%), kategori kreatif sedikit turun dari OC3, yakni 17 karya (56,66\%), dan kurang kreatif 11 karya (36,66\%).

Analisis di atas menunjukkan bahwa ada peningkatan kreativitas mahasiswa dalam menulis puisi, meskipun belum stabil atau masih flungtuatif, tetapi tidak signifikan. Hal ini ditunjukkan oleh adanya perubahan kemampuan mahasiswa dalam memanfaatkan persajakan dan penggunaan imaji dan bahasa figuratif. Dalam penulisan puisi kedua unsur tersebut (rima dan penggunaan bahasa figuratif) sangat penting dalam menggugah pengalaman sensoris pembaca. Begitu juga dengan meningkatnya kreativitas dalam penggunaan bahasa figuratif, berarti hasil karya mahasiswa dapat menghasilkan kesenangan imajinatif, puisi lebih nikmat dibaca, lebih menambah intensitas penyair/penulisnya, dan dapat megkonsentrasikan makna yang hendak disampaikan.

\section{d. Peningkatan Kualitas Pembelajaran}

Dari segi kulialitas pembelajaran, terjadi juga peningkatan kualitas proses pembelajaran. Wujud konkret dari peningkatan ini tampak dari data angket yang disebarkan kepada mahasiswa (sebanyak 20), dibagikan secara acak dan kembali 10 angket (pada tanggal 29 November 2014), setiap butir soal angket dijawab "ya" oleh mahasiswa, hanya 1 orang menjawab "tidak" pada butir soal no. 3 dan no. 12. Jadi 90\% mahasiswa (responden) beranggapan, bahwa pembelajaran dengan model Kreatif dan Produktif menarik dan menyenangkan, memotivasi mahasiswa, mendorong kerja sama yang aktif, mendorong kemandirian, dan lain-lain. Hal ini juga didukung oleh hasil pengamatan tim observer, sejak OC1 sampai OC4, simpulannya interaksi antarmahasiswa dari OC1 ke OC berikutnya semakin membaik, tujuan yang digariskan telah tercapai. Yang lebih penting lagi disampaikan komentar tim pendamping (Dr. Ibrohim) pada OC4, sebagai beikut:

- Kegiatan pembelajaran menarik sekali. Hampir tidak ditemukan mahasiswa yang tidak aktif karena memang menuntut kerja individu.

- Proses saling tukar-menukar hasil kerja sangat menarik sehingga mereka tidak hanya diharapkan mampu menulis, tetapi juga mampu berkomenntar.

- Cara presentasi sangat baik, yang satu presentasi dan satu lagi mengomentari atau memberikan penilaian tentang puisi sehingga terfokus.

- Pancingan dengan menggunakan video sangat menarik, mereka kreatif untuk menulis puisi. 
- Penggunaan IT sangat baik. Hasil kerja kelompok langsung diambil gambarnya kemudian ditampilkan pada slide, sehingga semua kelompok mampu mencermati.

- Penayangan video nanti sebaiknya ada audio supaya lebih menarik.

- Pengelolaan kelas sangat baik. Peralihan dari diskusi kelompok ke diskusi kelas, posisi duduk mahasiswa sudah diatur dulu.

- Ulasan terakhir sangat bagus, tidak terlalu banyak tetapi sangat efektif/mengena.

- SAP perlu dicermati dari segi penulisan, kalau sistematika sudah tepat.

- Indikator 1 sepertinya ada yang kurang, seharusnya "Mengidentifikasi masalahmaslaha apa?"

- Langkah-langkah pembelajaran, antara menyaksikan dan menulis sepertinya ada langkah yang harus dilakukan dulu.

- Pembacaan puisi mahasiswa sesuai tanggapan dosen memang benar. Cara mereka membaca masih kurang.

\section{Penutup}

Penerapan model pembelajaran kreatif dan produktif berbasis masalah-masalah kontekstual melalui kegiatan lesson study di dalam pembelajaran Penulisan Kreatif Sastra, khususnya pada masalah ekspresi tulis puisi modern dapat meningkatkan kreativitas mahasiswa. Model pembelajaran kreatif dan produktif dapat meningkatkan kualitas pembelajaran Penulisan Kreatif Sastra. Hal ini tampak pada meningkatnya keaktifan, kemandirian, kerja sama, dan motivasi mahasiswa dalam menyelesaikan tugas-tugas dalam pembelajaran. Perlu juga digarisbawahi, mahasiswa menganggap pembelajaran ini menarik dan menyenangkan.

\section{Daftar Pustaka}

Depdiknas, Dirjen Dikti, Direktorat Pembinaan Tenaga Kependidikan dan Ketenagaan Perguruan Tinggi. (2005). Peningkatan Kualitas Pembelajaran. Jakarta.

Herpinus Simanjuntak. (1997). Kamus Sinonim Antonim. Jakarta: Kesaint Blanc.

Ibrohim. (2013). "Implementasi Lesson Study untuk Meningkatkan Kompetensi Pendidik, Kualitas Pembelajaran di Sekolah dan LPTK Serta Perkembangannya di Indonesia" Makalah disajikan dalam Work Shop Sosialisasi Lesson Studi Program LEDIPSTI Sekolah Tinggi Keguruan dan Ilmu Pendidikan Hamzanwadi Selong, 19--20 April 2013. 
Sabarti Akhadiah, dkk. (1996). Menulis. Departemen Pendidikan dan Kebudayaan, Dirjen Dikdasmen, Bagian Proyek Penyetaraan Guru SLTP Setara D-III.

Setiawati, Eti, dkk. (2009). Lesson Studi Berbasis MGMP Bahasa Indonesia SMA seJayapura. Malang: Surya Pena Gemilang.

Suhirman, Lalu. (2016). Lesson Study Based for Advancing Teacher's Pedagogical Competence and Profesional Development (Summary of Dissertation). English Education Post Graduate Program, State University of Makassar.

Tim Perluasan dan Penguatan Lesson Study. (2013). "Buku Panduan Pelaksanaan Lesson Study Berbasis Hirarkhi Prose”. STKIP Hamzanwadi Selong.

Tim Redaksi Nuansa Auliya. (2006). Himpunan Perundang-undangan Republik Indonesia tentang Guru dan Dosen. Bandung: Nuansa Auliya.

Waluyo, Herman. (1987). Teori dan Apresiasi Puisi. Jakarta: Erlangga.

Yoyo Mulyana, dkk. (1997). Sanggar Sastra. Jakarta: Direktorat Pendidikan Guru dan Tenaga Teknis. 